\title{
Meningkatan Keterampilan Berbicara Melalui Media Boneka Tangan Pada Anak Kelompok B Di Taman Kanak-Kanak Negeri Dewi Kayangan Tahun Pelajaran
} 2019-2020

\author{
${ }^{1}$ M. Arzani, ${ }^{2}$ Lalu Marzoan \\ ${ }^{12}$ Dosen STKIP Hamzar \\ ${ }^{1}$ zanarzan25@gmail.com, ${ }^{2}$ zoanzakiya12@gmail.com
}

\begin{abstract}
Abstrak
Tujuan Penelitian ini adalah untuk meningkatkan keterampilan berbicara anak melalui media boneka tangan pada anak kelompok B di TK negeri dewi kayangan. Penelitian tindakan kelas kolaboratif yang menggunakan model Kemmis dan Mc Taggart yang dilakukan dalam dua siklus. Subjek penelitian ini sebanyak 25 anak 13 anak laki-laki dan 12 anak perempuan. Objek penelitian ini adalah keterampilan berbicara melalui media boneka tangan. Teknik pengumpulan data yang digunakan adalah observasi (lembar observasi), wawancara (kisi-kisi wawancara untuk guru), dan dokumentasi (catatan catatan selama proses kegiatan berlangsung, gambar atau foto, dan RKH). Teknik analisis data dilakukan secara deskriptif kualitatif dan kuantitatif. Kriteria keberhasilan dalam penelitian ini apabila keterampilan berbicara anak telah mencapai 80\% dengan kriteria sangat baik. Dari hasil penelitian menunjukkan adanya peningkatan pada keterampilan berbicara melalui media boneka tangan pada anak Kelompok B di TK Negeri Dewi Kayangan. Hasil observasi yang dilakukan pada saat Pratindakan menunjukkan bahwa keterampilan berbicara anak mencapai 40,96\% dengan kriteria cukup, pada Siklus I meningkat mencapai 68,08\% dengan kriteria cukup, dan pada Siklus II meningkat mencapai $87,92 \%$ dengan kriteria sangat baik. Langkah-langkah yang ditempuh untuk meningkatkan keterampilan berbicara melalui media boneka tangan yaitu sebagai berikut: 1) Guru bercerita menggunakan boneka tangan; 2) Guru mengelompokkan anak, tiap kelompok terdiri dari dua dan tiga anak; 3) Anak-anak mengulang kembali cerita yang telah disampaikan oleh guru; serta 4) Guru memberikan motivasi dan reward berupa "Tanda Bintang".
\end{abstract}

Kata kunci : Keterampilan berbicara, media boneka tangan, anak Kelompok B 


\section{PENDAHULUAN}

Pendidikan anak usia dini (PAUD) adalah jenjang pendidikan sebelum jenjang pendidikan dasar yang merupakan suatu upaya pembinaan yang di tujukan bagi anak sejak lahir hingga usia enam tahun yang dilakukan dengan pemberian rangsangan pendidikan untuk membantu pertumbuhan dan perkembangan jasmani dan rohani agar anak memiliki kesiapan dalam memasuki pendidikan lebih lanjut yang di selenggarakan pada jalur formal, nonformal dan informal.

kecerdasan bahasa adalah kecerdasan yang paling sering digunakan. Manusia berkomunikasi dengan menggunakan bahasa. Kecerdasan berbahasa adalah kecerdasan yang berhubungan dengan kemampuan untuk melakukan sekaligus memahami informasi dan komunikasi kepada orang lain, baik secara lisan maupun tulisan. Kecerdasan ini mencakup kepekaan terhadap arti kata, urutan kata, suara, ritme, dan intonasi dari kata yang diucapkan, termasuk kemampuan untuk mengerti kekuatan kata dalam mengubah kondisi pikiran dan menyampaikan informasi. Dan perkembangan bahasa anak sangat penting, karena melalui bahasa anak dapat menyampaikan keinginan, pikiran, harapan maupun permintaan serta dapat bergaul dengan sesama di lingkungannya. Dengan komunikasi yang baik, yang diperdengarkan oleh orang tua maupun pendidik maka anak akan lebih mudah untuk mempelajari dari apa yang ia dengar dan lihat, sehingga bahasa anak dapat dilihat dari apa yang ia ucapkan saat berbicara dengan temannya.

Mulgrave, (1954 : 16) Dalam Henry Guntur Tarigan. Berbicara adalah kemampuan mengucapkan bunyi-bunyi artikulasi atau katakata untuk mengekspresikan, menyatakan atau menyampaikan pikiran, gagasan dan perasaan. Berbicara merupakan suatu sistem tanda-tanda yang dapat didengar (audible) dan yang kelihatan (visible). Dengan demikian, maka berbicara itu lebih daripada hanya sekedar pengucapan kata-kata. Berbicara adalah suatu alat untuk mengkomunikasikan gagasangagasan yang disusun serta dikembangkan sesuai dengan kebutuhan sang pendengar atau penyimak. Berbicara juga termasuk pengembangan bahasa yang merupakan salah satu bidang yang perlu dikuasai oleh anak usia dini. Pada masa ini anak usia dini memerlukan berbagai rangsangan yang dapat meningkatkan perkembangan bahasa anak, sehingga dengan pemberian rangsangan yang tepat pada anak maka bahasa anak dapat tercapai dengan optimal.

Madyawati (2016), mengemukakan bahwa Media merupakan saluran komunikasi, media bisa dipertimbangkan sebagai media pembelajaran pembawa pesan-pesan dalam rangka mencapai tujuan pembelajaran. Pemakaian media pembelajaran dalam proses belajar mengajar dapat membangkitkan keinginan, minat yang baru, membangkitkan motivasi dan rangsangan kegiatan belajar, bahkan membawa pengaruh-pengaruh psikologi terhadap siswa. Media yang baik dan tepat dalam pembelajaran dapat meningkatkan aspek perkembangan salah satunya adalah aspek bahasa dalam hal peningkatan keterampilan berbicara. Media yang digunakan peneliti untuk meningkatkan keterampilan berbicara anak adalah media boneka tangan. Keuntungan menggunakan media boneka tangan yaitu dapat mengembangkan bahasa anak, meningkatkan kreatifitas dan keterampilan anak, belajar bersosialisasi dan melatih jari jemari tangan anak. Dengan menggunakan media boneka tangan, maka akan lebih menarik perhatian dan minat anak terhadap kegiatan pembelajaran, membantu mengembangkan emosi anak, anak dapat mengekspresikan emosi dan kekehawatirannya melalui boneka tangan tanpa merasa takut ditertawakan dan diolok-olok temannya.

Kenyataan yang ada di lapangan peningkatan keterampilan berbicara anak di Taman Kanak-Kanak belum maksimal dalam peningkatan keterampilan berbicara. Ketidak mampuan anak dalam berkomunikasi secara lisan ini dikarenakan beberapa alasan, salah satu alasan tersebut yaitu kegiatan pembelajaran 
yang kurang diperhatikan aspek-aspek perkembangan bahasa anak.

Berdasarkan permasalahan tersebut, keterampilan berbicara anak pada kelompok B di TK Negeri Dewi Kayangan masih belum optimal. Belum optimalnya keterampilan berbicara anak dikarenakan masih sedikitnya memberikan kesempatan untuk anak mengungkapkan (ide, pikiran, gagasan dan perasaan) melalui komunikasi lisan, metode pembelajaran masih kurang bervariasi sehingga anak cepat merasa jenuh atau bosan mengikuti pembelajaran. Hal ini juga dikarenakan belum adanya media yang menarik dan berupaya untuk melatih keterampilan berbicara pada anak kelompok B di TK Negeri Dewi Kayangan. Dalam rangka mengatasi persoalan di atas, peneliti ingin meningkatkan keterampilan berbicara anak taman kanak-kanak melalui media boneka tangan.

\section{KAJIAN PUSTAKA \\ Keterampilan berbicara}

Keterampilan

adalah

kemampuan anak dalam melakukan berbagai aktivitas seperti motorik, berbahasa, social emosional, kognitif dan efektif Yudha M. Saputra \& Rudyanto, (2005). Kata keterampilan sama artinya dengan kata kecekatan, terampil atau cekatan adalah kepandaian.

Menurut Hurlock (1978: 12.13) mengemukakan bahwa berbicara adalah bentuk bahasa yang menggunakan artikulasi atau katakata yang digunakan untuk menyampaikan ide yang akan diungkapkan.

Keterampilan berbicara merupakan kemampuan anak dalam menyampaikan maksud melalui kata-kata tentang ide, gagasan dan perasaan yang ada dalam diri anak. Anak belajar bersosialisasi dengan lingkungan melalui bicara, sehingga berbicara menjadi alat komunikasi dan sumber informasi bagi anak. Karena melalui berbicara anak dapat mengenal lingkungan dan dunianya serta dapat merangsang aspek perkembangan yang dimiliki oleh anak itu sendiri.
Nurbiana, Dkk. (2005 : 29.30), menyatakan bahwa karakteristik umum kemampuan bahasa pada anak usia 5-6 tahun adalah sebagai berikut:

1. Kemampuan anak untuk dapat berbicara dengan baik.

2. Melaksanakan tiga perintah lisan secara berurutan dengan benar.

3. Mendengarkan dan menceritakan kembali cerita sederhana dengan urutan yang mudah difahami, menyebutkan nama, jenis kelamun dan umurnya.

4. Menggunakan kata sambung seperti : dan, karena, tetapi.

5. Menggunakan kata Tanya seperti bagaimana, apa, mengapa dan kapan.

6. Membandingkan dua hal yang memiliki persamaan atau perbedaan.

7. Memahami konsep timbale balik.

8. Dapat menyusun kalimat.

9. Mengucapkan lebih dari tiga kalimat : serta.

10. Mengenal tulisan sederhana yang dilihatnya.

\section{Media Pembelajaran}

Kata media berasal dari bahasa latin medius, merupakan bentuk jamak dari kata medium yang secara harfiah berarti perantara atau pengantar. Menurut Gerlach \& Ely (1971), Dalam Mukhtar Latif, Dkk. Media adalah bila difahami secara garis besar adalah manusia, materi, atau kejadian yang membangun kondisi yang membuat siswa mampu memperoleh pengetahuan keterampilan, atau sikap.

\section{Tujuan Media Pembelajaran}

Menurut Sanaky (2013) tujuan media sebagai alat bantu pembelajaran adalah untuk:

1. Mempermudah pembelajaran di kelas.

2. Meningkatkan efisiensi proses pembelajaran.

3. Menjaga relevansi antara materi pelajaraan dengan tujuan pelajaran.

4. Membantu konsentrasi siswa dalam proses pembelajaran.

\section{Fungsi Media Pembelajaran}

Fungsi media pembelajaran adalah sebagai alat bantu mengajar yang turut mempengaruhi kondisi dan lingkungan yang 
ditata dan diciptakan oleh guru Suryani \& Agung S, (2012). Adapun Sanaky (2013) berpendapat bahwa media pembelajaran berfungsi untuk merangsang dengan :

1. Menghadirkan objek sebenaarnya

2. Membuat tiruan dari objek sebenarnya

3. Membuat konsep abstrak ke konsep yang lebih kongkrit

4. Menyamakan persepsi

5. Mengatasi hambatan waktu, tempat, jumlah dan jarak

6. Menyajikan ulang informasi secara konsisten

7. Memberi suasana belajar yang menyenangkan dan menarik sehingga tujuan pembelajaran tercapai.

\section{Manfaat Media Pembelajaran}

Adapun manfaat yang dapat diperoleh dari media pembelajaran ialah :

1. Pesan atau informasi pembelajaran dapat disampaikan dengan lebih jelas, menarik, kongkrit dan tidak hanya dalam bentuk kata-kata tertulis atau lisan belaka (verbalistis).

2. Mengatasi keterbatasan ruang, waktu dan daya indra.

3. Meningkatkan sikap aktif siswa dalam belajar.

4. Menimbulkan kegairahan dan motivasi dalam belajar.

5. Memungkinkan interaksi yang lebih langsung antara siswa dengan lingkungan dan kenyataan.

6. Memungkinkan siswa belajar sendirisendiri menurut kemampuan dan minatnya.

7. Memberikan rangsangan, pengalaman, dan persepsi yang sama bagi siswa.

\section{Media Boneka Tangan}

\section{Pengertian Boneka Tangan}

Media boneka tangan adalah boneka yang dijadikan media atau alat bantu yang digunakan dalam kegiatan pembelajaran. Jenis boneka tangan yang digunakan adalah boneka tangan yang terbuat dari potongan kain. Boneka tangan ini ukurannya lebih besar dari boneka jari dan dapat dimasukkan ke dalam tangan. Jari tangan dapat dijadikan pendukung gerakan tangan dan kepala boneka. Gunarti, (2013: 184). Jadi, boneka tangan ini yang dijadikan sebagai media atau alat bantu yang digunakan dalam kegiatan pembelajaran, yang berukuran lebih besar dari pada boneka jari dan dimasukkan ke dalam tangan.

\section{Manfaat Boneka Tangan}

Salsabila (2012 : 186.187) Dalam Lilis Madyawati, Ada beberapa manfaat yang diambil dari permainan menggunakan media boneka tangan ini, diantaranya adalah :

1. Membantu anak membangun keterampilan sosial.

2. Melatih kemampuan menyimak (ketika mendengarkan teman saaling bercerita).

3. Melatih sabar dan menanti giliran.

4. Meningkatkan kerja sama.

5. Motivasi anak agar mau tampil.

6. Meningkatkan keaktifan anak.

7. Menambah suasana gembira dalam kegiatan pembelajaran.

8. Tidak menuntut keterampilan yang rumit bagi yang memainkannya.

9. Tidak memerlukan waktu yang banyak, biaya, dan persiapan yang rumit.

Berdasarkan uraian di atas, maka pengertian boneka tangan adalah boneka yang terbuat dari kain yang dibentuk menyerupai wajah dan bentuk tubuh dari berbagai bentuk dengan berbagai macam jenis sifat yang dimainkan dengan menggunakan jari-jari tangan.

\section{Kelebihan dan Kekurangan Media Boneka} Tangan

Beberapa kelebihan media boneka tangan, menurut madyawati (2014):

1. Umumnya anak menyukai boneka. Dengan menggunakan media boneka tangan, maka akan lebih menarik perhatian dan minat anak terhadap kegiatan pembelajaran.

2. Membantu mengembangkan emosi anak. Anak dapat mengekspresikan emosi dan kekehawatirannya melalui media boneka tangan tanpa merasa takut ditertawakan dan diolok-olok temannya.

3. Membantu anak membedakan fantasi dan realita. 
tangan

Beberapa kekurangan media boneka

1. Guru harus meluangkan waktu untuk mempersiapkan media media boneka tangan, kreasi gerakan, mimik, suara, dan kegiatan kelasnya.

2. Keragaman siswa merupakan kendala lain karena guru harus memahami mereka secara individual.

3. Dapat membedakan antara suara boneka satu dengan boneka yang lainnya.

Dari penjelasan di atas dapat disimpulkan bahwa kelebihan menggunakan media boneka tangan dapat menarik perhatian siswa serta dengan menggunakan media boneka tangan dapat membuat anak lebih mengerti dan faham karena objek tersebut ada di hadapan mereka.

\section{Langkah-langkah \\ Menerapkan Keterampilan Berbicara Melalui Media Boneka Tangan.}

Menurut Rachmawati dkk (2005), mengemukakan beberapa penerapan untuk meningkatkan keterampilan berbicara sebagai berikut :

1. Rumuskan tujuan pembelajaran yang jelas, dengan demikian akan dapat diketahui apakah dapat penggunaan boneka tanganuntuk kegiatan pembelajaran.

2. Buatlah naskah atau sekenario sandiwara boneka tangan dengan jelas dan terarah.

3. Hendaknya diselingi dengan nyanyian agar menarik perhatian anak dan anak diajak untuk bernyanyi bersama-sama.

4. Permainan boneka tangan ini hendaknya jangan lama.

5. Isi cerita sesuai dengan umur dan daya imajinasi anak.

6. Selesai permainan boneka tangan hendaknya berdiskusi tentang peran yang telah dilaksanakan.

Berdasarkan uraian di atas, maka dapat disimpulkan bahwa pembelajaran boneka tangan harus memiliki tujuan yang jelas. Pada saat pembelajaran berlangsung hendaknya pembelajaran boneka tangan jangan terlalu lama, karena anak akan cepat bosan terhadap kegiatan yang memakan waktu yang lama. Akan lebih baik ketika bercerita menggunakan media boneka tangan diselingi dengan lagu atau mengajak anak untuk bernyanyi agar anak tidak mudah bosan. Setelah selesai kegiatan pembelajran boneka tangan hendaknya guru melakukan dialog atau Tanya jawab kepada anak, supaya anak memahami dari semua kegiatan tersebut. Setelah kegiatan Tanya jawab, anak diberikan kesempatan untuk menggunakan media boneka tangan tersebut.

\section{Kerangka Berfikir}

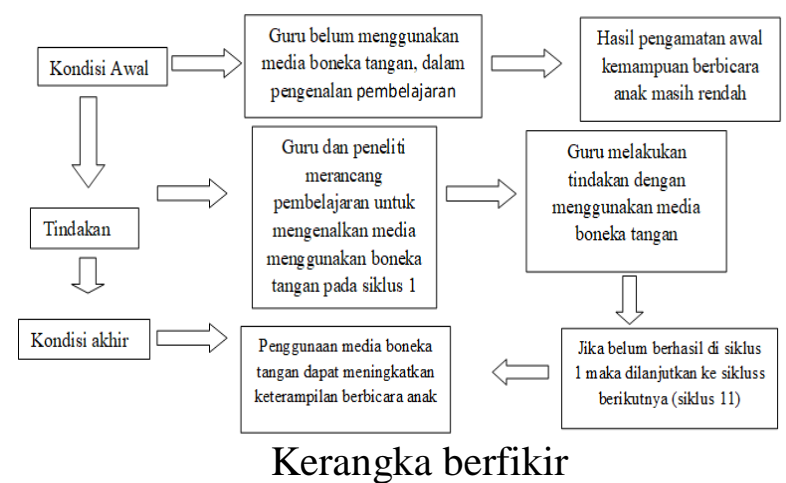

\section{Hipotesis Tindakan}

hipotesis tindakan dalam penelitian ini adalah Media boneka tangan dapat meningkatkan keterampilan berbicara anak kelompok B di TK Negeri Dewi Kayangan, Kabupaten Lombok Utara Tahun Pelajaran 2019/2020

\section{METODE PENELITIAN}

\section{Jenis Penelitian}

Penelitian ini dilakukan dengan menggunakan Penelitian Tindakan Kelas (PTK). Suharsimi arikunto mengemukakan bahwa Penelitian tindakan kelas adalah penelitian yang memaparkan terjadinya sebab-akibat dari perlakuan, sekaligus memaparkan apa saja yang terjadi ketika perlakuan diberikan, dan memaparkan seluruh proses sejak awal pemberian perlakuan sampai dengan dari perlakuan tersebut. 
Penelitian ini dilaksanakan pada semester ganjil tahun pelajran 2019-2020. rencana kegiatan penelitian ini berlangsung selama Dua Bulan. Pelaksanaan penelitian tindakan kelas dilakukan dua siklus, yang akan dilaksanakan di Taman Kanak-Kanak Negeri Dewi Kayangan kelompok B usia 5-6 tahun.

\section{Subjek Penelitian}

Subjek penelitian ini adalah anak-anak kelompok B Taman Kanak-Kanak Negeri Dewi Kayangan Kabupaten Lombok Utara, tahun ajaran 2019-2020, dengan Jumlah siswa 25 anak, yang terdiri dari 12 anak perempuan dan 13 anak laki-laki. Peneliti memilih kelompok B di karenakan usia kelompok B akan memasuki sekolah dasar yaitu berada pada rentang usia 5-6 tahun dan keterampilan berbicara belum optimal.

\section{Sumber Data}

Sumber data dalam penelitian ini adalah didapat secara langsung, yang dimana peneliti memilih informasi yang akan digunakan sebagai sumber data yang dianggap mampu memberikan informasi yang jelas terhadap data yang diperlukan pada saat melakukan penelitian. Adapun sumber data dari penelitian ini adalah Guru, Peserta Didik dan orang tua Wali

Pengambilan data yang dihimpun langsung oleh peneliti disebut sumber primer, sedangkan yang melalui tangan kedua disebut sumber sekunder. Selain itu sumber data dalam penelitian ini adalah data primer yang mana peneliti mengumpulkan data dengan cara menghimpun langsung dari objek penelitian yang dilakukan ini yaitu, peserta didik kelompok B di TK Negeri Dewi Kayangan Desa Kayangan Kecamatan Kayangan Kabupaten Lombok Utara Tahun Pelajaran 2019-2020.

\section{Tehnik dan Alat Pengumpulan Data}

Tehnik pengumpulan data adalah cara yang digunakan untuk memperoleh data yang dibutuhkan (Arikunto, 2010:175). Tehnik pengumpulan data dalam penelitian ini yaitu tehnik Observasi, wawancara dan dokumentasi.

\section{Validasi Data}

Sugiyono menjelaskan bahwa, Penelitian tindakan kelas harus memenuhi kriteria validitas penelitian tindakan dasar validitas dalam penelitian kualitatif, yaitu makna langsung dan lokal dari tindakan sebatas sudut pandang peserta penelitiannya. Validitas berkenaan dengan alat ukur terhadap konsep yang diukur, sehingga betul-betul mengukur apa yang seharusnya diukur. suatu alat ukur akan dikatakan valid atau mempunyai nilai validitas tinggi apabila alat ukur tersebut memang dapat mengukur apa yang kita ukur. Validitas instrument sangat dibutuhkan dalam suatu penelitian, karena validitas juga merupakan ukuran mutu dan kebermaknaan suatu penelitian. Suatu penelitian tidak akan memiliki arti apa-apa jika alat ukurnya tidak valid, oleh karena itu instrument tersebut mungkin mengumpulkan data yang berbeda dengan yang kita kehendaki. Adapun cara yang dapat dilakukan untuk memvalidasi data yaitu menggunakan kegiatan tanya jawab dengan cara bertanya mengenai boneka tangan yang ada di depan guru.

\section{Analisis Data}

Tujuan analisis dalam penelitian tindakan kelas ini adalah untuk memperoleh kepastian apakah terjadi perbaikan, peningkatan atau perubahan sebagaimana yang diharapkan bukan untuk membuat generalisasi atau pengujian teori semata.

Penelitian tindakan kelas ini mengandung campuran data kualitatif dan kuantitatif. Analisis data kualitatif dilakukan berupa hasil observasi lapangan sedangkan data kuantitatif dilakukan melalui perhitungan persentase hasil penelitian yang dilakukan. Untuk mengetahui hasil persentase keterampilan berbicara, maka data dianalisis menggunakan analisis deskriptif kuantitatif.

\section{Indikator Kinerja}

Indikator keberhasilan dalam penelitian ini mengenai keterampilan berbicara pada anak kelompok B melalui media boneka tangan akan terlihat dari proses pembelajaran yang sesuai dengan indikator keberhasilan yang telah ditetapkan.

Indikator keberhasilan dalam penelitian ini adalah ditandai dengan adanya perubahan 
menuju arah perbaikan. Indikator dapat dikatakan berhasil apabila keterampilan berbicara anak mengalami peningkatan sebesar 80\% dari 25 jumlah anak Kelompok B TK Negeri Dewi Kayangan, yaitu 21 anak mencapai indicator keberhasilan keterampilan berbicara dengan kriteria baik.

\section{Prosedur Penelitian}

Penelitian tindakan dapat dipandang sebagai suatu siklus spiral dan penyusunan, perencanaan, tindakan, pengamatan (observasi) dan refleksi yang diikuti dengan siklus spiral berikutnya dalam pelaksanaannya ada kemungkinan peneliti telah mempunyai seperangkat rencana tindakan (yang didasarkan pada pengalaman) sehingga dapat langsung memulai tahap tindakan. Penelitian ini menggunakan model penelitian yang dikemukakan oleh Kemmis dan Mc Taggart (Sumber : Suharsimi Arikunto, 2002 )

\section{Siklus I}

Pertemuan Pertama : Metode tanya jawab. Guru menceritakan alur cerita dan anak sebagai pendengar cerita. Pada kegiatan pertama, guru akan bertanya kepada tiap anak berkaitan dengan cerita yang telah disampaikan.

Pertemuan Kedua : Metode individu. Guru meminta anak maju satu per-satu untuk bercerita menggunakan media boneka tangan. Pertemuan Ketiga : Metode berpasangan. Guru meminta tiap anak untuk berpasangan bercerita menggunakan media boneka tangan dengan temannya.

\section{Siklus II}

Pertemuan Pertama : Metode berkelompok. Guru membentuk kelompok, tiap kelompok terdiri dari tiga dan empat anak, masing-masing kelompok bercerita menggunakan media boneka tangan.

Pertemuan Kedua : Metode berkelompok. Guru membentuk kelompok, tiap kelompok terdiri dari tiga dan empat anak, masing-masing kelompok bercerita menggunakan media boneka tangan.

\section{Pelaksanaan dan Pengamatan}

Pelaksanaan tindakan dilakukan oleh guru kelas dan peneliti, peneliti melakukan pengamatan selama kegiatan pembelajaran berlangsung sampai selesai. Guru dan peneliti melakukan proses pembelajaran sesuai dengan yang telah tercantum dalam RKH yang sudah dibuat bersama. Pembelajaran yang dilaksanakan terdapat penggunaan media boneka tangan yang sebelumnya telah disampaikan oleh peneliti. Dalam satu siklus, penelitian dilakukan tiga kali pertemuan, dengan durasi waktu masing-masing kurang lebih 60 menit.

Tahap pengamatan dilakukan oleh observer, dalam hal ini oleh peneliti. Pelaksanaan tahap ini dilakukan bersamaan dengan berlangsungnya tindakan yang memuat kegiatan pembelajaran menggunakan media boneka tangan untuk meningkatkan keteramilan berbicara anak usia 5-6 tahun. Tujuan dilakukannya pengamatan adalah untuk mengumpulkan bukti hasil tindakan yang sudah dilaksanakan agar dapat dievaluasi dan dijadikan landasan bagi pengamat dalam melakukan refleksi untuk menyusun rencana ulang memasuki siklus berikutnya.

Pengamatan berpedoman pada lembar instrument pengamatan berupa panduan observasi yang berisi tentang keterampilan berbicara yang digunakan dalam penelitian ini adalah anak mampu untuk menyampaikan maksud (ide,pikiran,gagasan dan perasaan) dengan lancar dan jelas, kemampuan sisiwa membuat kalimat sederhana dalam bahasa lisan dan struktur lengkap.

\section{Refleksi}

Refleksi merupakan bagian untuk mengemukakan kembali apa yang sudah dilakukan. Peneliti melakukan refleksi setelah tahap pelaksanaan tindakan dan pengamatan selesai dilaksanakan. Kegiatan yang dilakukan pada tahap ini adalah:

1. Pengumpulan data atau hasil observasi, baik berupa lembar observasi, lembar wawancara dan dokumentasi kegiatan.

2. Diskusi antara guru dengan peneliti yang bertujuan untuk mengevaluasi hasil tindakan 
yang telah dilakukan dengan cara melakukan penelitian terhadap proses yang terjadi, masalah yang muncul, dan segala hal yang berkaitan dengan tindakan yang dilakukan.

3. Mencari jalan keluar terhadap masalahmasalah yang mungkin timbul agar dapat diperbaiki pada siklus berikutnya.

4. Pengambilan keputusan. Apabila dari hasil pengamatan ternyata belum mencapai target, maka dengan demikian tindakan berikutnya yaitu berlanjut pada siklus II dengan tujuan untuk memperbaiki pembelajaran. Siklus tersebut dilakukan berkelanjutan sampai ada peningkatan seperti yang diharapkan dalam keterampilan berbicara anak.

5. Jika penelitian dianggap cukup karena sudah mencapai target yang diharapkan, maka refleksi terakhir dilakukan dengan membuat catatan-catatan secara rinci. Hal ini bertujuan untuk memberikan informasi bagi siapapun yang akan melaksanakan penelitian dalam kesempatan lain.

\section{HASIL PENELITIAN}

Penelitian ini dilaksanakan di TK Negeri Dewi Kayangan yang letaknya dipinggir jalan raya pendidikan tepatnya didusun Karang Lande, Desa Kayangan, Kecamatan Kayangan, Kabupaten Lombok Utara.

Sebelum dilakukan penelitian tindakan kelas, peneliti melakukan pengambilan skor terhadap keterampilan berbicara melalui media boneka tangan dengan menggunakan tekhnik observasi. Pelaksanaan pratindakan ini dilakukan untuk mengetahui keterampilan berbicara anak melalui media boneka tangan sebelum dilakukannya tindakan. Guru sebagai pelaksana pembelajaran melakukan pratindakan sebelum Siklus I yaitu pada hari Senin tanggal 21 Oktober 2019. Pelaksanaan pratindakan ini menggunakan tiga tekhnik pengumpulan data yaitu Observasi, Wawancara dan dokumentasi yang berupa lembar observasi check list, catatan selama proses kegiatan berlangsung dan foto selama kegiatan berlangsung serta Rencana Kegiatan Harian dan lembar wawancara.

Hasil keterampilan berbicara pada pratindakan ini menunjukkan bahwa keterampilan berbicara melalui media boneka tangan pada anak kelompok B di TK Negeri Dewi Kayangan perlu ditingkatkan. Upaya peningkatan keterampilan berbicara dengan media boneka tangan. Kegiatan bermain boneka tangan dikemas dengan pembagian kelompok yang selalu diawasi dan didampingi oleh guru.

Hasil dari pratindakan menggunakan lembar observasi (checklist) pada indicator menyampaikan maksud (ide, pikiran, gagasan dan perasaan) pada ana kelompok B, membuat kalimat sederhana mencapai 40,96\% hal ini merupakan termasuk kriteria kurang baik. Keadaan seperti ini menjadi suatu landasan bagi peneliti untuk melakukan sebuah tindakan dalam rangka meningkatkan keterampilan berbicara.

\section{Siklus I}

Hasil pengamatan siklus I pada pertemuan 1 dan 2 menunjukkan bahwa keterampilan berbicara menggunakan media boneka tangan pada dapat diketahui bahwa indicator dalam mengetahui keterampilan berbicara anak pada siklus I menyampaikan maksud (ide, pikiran, gagasan dan perasaan), indicator membuat kalimat sederhana dan ratarata keterampilan berbicara pada Siklus I mencapai $68,08 \%$ atau termasuk kriteria cukup.

\section{Siklus II}

Berdasarkan hasil Observasi yang diperoleh dari pelaksanaan Siklus II apabila dibandingkan dengan Siklus I terlihat ada peningkatan yang cukup signifikan dan telah mencapai indikator keberhasilan lebih dari $80 \%$.

Pencapaian keterampilan berbicara sesudah tindakan pada indikator menyampaikan maksud (ide, pikiran, gagasan, perasaan) dengan lancar dan jelas, membuat kalimat sederhana dengan bahasa lisan dan struktur lengkap pencapaian keterampilan berbicara pada Siklus II mencapai $87,92 \%$ dengan mencapai kriteria baik.

Anak begitu antusias mengikuti pembelajaran karena pembelajaran dari guru membuat anak senang dan tertarik 
mengikutinya, sehingga anak tidak ramai sendiri. Pada Siklus II keterampilan berbicara pada anak Kelompok B sudah mengalami peningkatan lebih dari $80 \%$ dengan indicator menyampaikan maksud (ide, pikiran, gagasan, dan perasaan) dengan lancar dan jelas, membuat kalimat sederhana dengan bahasa lisan dan struktur lengkap telah memenuhi indikator keberhasilan mencapai 87,92\% sehingga penelitian dirasa cukup dan dihentikan sampai Siklus II.

\section{Pembahasan}

Dari hasil penelitian dapat dilihat adanya peningkatan keterampilan berbicara anak melalui media boneka tangan. Penelitian ini dilakukan selama lima kali tatap muka yang terbagi dalam dua siklus. Siklus I dilaksanakan selama tiga kali pertemuan dan Siklus II dilakukan selama dua kali pertemuan. Hal ini telihat adanya peningkatan pada Siklus II yaitu mencapai kriteria tingkat keberhasilan sebesar $80 \%$.

Berdasarkan hasil penelitian yang dilakukan dan berkolaborasi dengan guru Kelompok B TK Negeri Dewi Kayangan yang dilakukan selama lima kali pertemuan dalam dua siklus. Siklus I dan Siklus II dengan tema yang sama yaitu Binatang. Menunjukan bahwa keterampilan berbicara anak melalui media boneka tangan mengalami peningkatan.

Pembelajaran di Taman Kanak-kanak harus dilakukan dengan menyenangkan. Banyak hal yang dapat dilakukan agar pembelajaran menyenangkan. Misalnya dengan menggunakan media pembelajaran yang menarik bagi anak. Salah satu media pembelajaran yang dapat digunakan untuk keterampilan berbicara pada TK Negeri Dewi Kayangan Kelompok B yaitu dengan menggunakan media boneka tangan. Dengan bentuk yang menarik dan anak dapat memainkan bonekanya dengan mudah sehingga efektif untuk digunakan. Guru dapat mendesain berbagai kegiatan yang memungkinkan anak untuk mengungkapkan ide, pikiran, gagasan dan perasaannya serta membuat kalimat sederhana.

Hal ini terlihat ketika anak Kelompok B di TK Negeri Dewi Kayangan dikenalkan dengan media boneka tangan oleh peneliti. Anak merasa senang, tertarik, dan lebih aktif dalam berbahasa. Ketika anak bermain boneka tangan secara tidak langsung aspek bahasa anak terlatih. Media boneka tangan ini membuat anak Kelompok B di TK Negeri Dewi Kayangan ini lebih tertarik lagi mengikuti pembelajaran terlihat pada Siklus II tingkat pencapaian indicator anak meningkat dari sebelum anak menggunakan media boneka tangan.

Boneka tangan digunakan sebagai media bermain dan belajar untuk anak yang dapat meningkatkan keterampilan berbicara. Peningkatan keterampilan berbicara pada anak dapat dilihat dengan meningkatnya keterampilan berbicara anak saat menggunakan media boneka tangan. keterampilan berbicara adalah mengucapkan bunyi-bunyi artikulasi atau katakata untuk mengekspresikan, menyatakan atau menyampaikan pikiran, gagasan, dan perasaan.

Pada saat di lapangan atau di dalam kelas, bahwa pada saat anak bermain boneka tangan pengucapan vocal anak jelas, baik dari intonasi, nada/irama, dan pemilihan ungkapan kata. Kemudian dalam segi non bahasa anak Kelompok B di TK Negeri Dewi Kayangan telah dapat mengekspresikan diri dalam memainkan media boneka tangan.

Boneka tangan digunakan sebagai media bermain dan belajar untuk anak yang dapat meningkatkan keterampilan berbicara. Peningkatan keterampilan berbicara pada anak dapat dilihat dengan meningkatnya keterampilan berbicara anak saat menggunakan media boneka tangan yaitu pada saat anak menyampaikan maksud (ide, pikiran, gagasan, dan perasaan), dan membuat kalimat sederhana. Senada dengan pendapat Henry Guntur Tarigan (1983: 15), bahwa keterampilan berbicara adalah mengucapkan bunyi-bunyi artikulasi atau katakata untuk mengekspresikan, menyatakan atau menyampaikan pikiran, gagasan, dan perasaan.

Greene \& Petty, (1971 : 3-4) dalam Tarigan. Linguis berkata bahwa "speaking is language". Berbicara adalah suatu keterampilan berbahasa yang berkembang pada anak, yang hanya di dahului oleh menyimak, dan pada masa 
tersebutlah kemampuan berbicara dipelajari. Berbicara sudah tentu berhubungan erat dengan perkembangan kosa kata yang diperoleh oleh sang anak; melalui kegiatan menyimak dan membaca. Sebelum kematangan dalam perkembangan bahasa juga merupakan suatu keterlambatan dalam kegiatan-kegiatan berbahasa.

Madyawati (2016), mengemukakan bahwa Media merupakan saluran komunikasi, media bisa dipertimbangkan sebagai media pembelajaran pembawa pesan-pesan dalam rangka mencapai tujuan pembelajaran. Pemakaian media pembelajaran dalam proses belajar mengajar dapat membangkitkan keinginan, minat yang baru, membangkitkan motivasi dan rangsangan kegiatan belajar, bahkan membawa pengaruh-pengaruh psikologi terhadap siswa. Media yang baik dan tepat dalam pembelajaran dapat meningkatkan aspek perkembangan salah satunya adalah aspek bahasa dalam hal peningkatan keterampilan berbicara. Media yang digunakan peneliti untuk meningkatkan keterampilan berbicara anak adalah media boneka tangan.

\section{KESIMPULAN}

Berdasarkan hasil penelitian, diperoleh kesimpulan bahwa penerapan media boneka tangan dapat meningkatkan keterampilan berbicara. Hal ini terbukti dari hasil penelitian menunjukkan peningkatan keterampilan berbicara dengan rata-rata ketercapaian anak Pratindakan mencapai 40,96\%, Siklus I mencapai $68,08 \%$, Siklus II mencapai $87,92 \%$. Hal tersebut telah mencapai kriteria keberhasilan penelitian sebesaar $80 \%$.

Peningkatan keterampilan berbicara anak meningkat melalui media boneka tangan, media dan penerapannya sesuai dengan langkahlangkah berikut : Guru menunjukkan boneka tangan kepada anak. 2. Guru mencontohkan cara menggunakan media boneka tangan. 3. Guru bercerita menggunakan media boneka tangan anak memperhatikan, setelah itu guru meminta anak untuk maju bercerita singkat tentang apa yang sudah guru sampaikan. Peningkatan keterampilan berbicara anak telah meningkat sesuai dari hasil penelitian yang telah dilakukan oleh peneliti anak sudah dapat bercerita sesuai kreativitasnya dan dengan bahasa yang lancar dan mudah dipahami oleh orang lain, guru teman dan orang tua. Keterampilan berbicara anak kelompok B melalui media boneka tangan selain itu pemberian kesempatan kepada anak untuk berbicara mengekspresikan diri menjadikan anak lebih terampil dalam berbicara.

\section{DAFAR PUSTAKA}

Agustina, Herliana., (2018). Meningkatkan Kemampuan Mengenal Huruf Hijaiah dengan Media Kartu Huruf. Lombok Utara : Proposal Skripsi.

Arikunto, Suharsimi., (2015). Penelitian Tindakan Kelas. Jakarta : Bumi Aksara.

Christiana, Hari Soetjiningsih., (2012). Perkembangan Anak Sejak Pembuahan Sampai dengan Kanak-kanak Akhir. Salatiga. Kencana.

Dhieni Nurbiana, dkk dalam Sari, Risti Lupita., (2014). Peningkatan Keterampilan Berbicara Melalui Media Boneka Tangan Kelompok B. E-journal Pendidikan AnakUsiaDiniUniversitasNegeriYogyakarta ,1179.Tersediadihttp://ejournal.uny.ac.id/in dex.php/jjPAUD.view/1.79.pdf. [diakses pada 07 april 2019] jam 01.56 WIB.

Fadilah, Nurul, Dkk., (2016). Peningkatan Berbicara Melalui Metode Bercakap-cakap pada Anak Kelompok B. Journal PAUD Universitas Sebelas Maret, 1-11. Tersedia di http://journal.USM.ac.id/index.php/paud/art icle.view/1.11.pdf.

Pada tanggal 20 juni 2019 jam 04.40 WIB.

Karlina, Dwi Nami., (2018). Kemampuan Berbicara Digital Storytelling. Journal Pendidikan Universitas Kristen Satya Wacana Salatiga, 1-11. Tersedia di http://doi.org.UKSWS.ac.id/10.21009/JPU D.121.01.pdf. [diakses pada 01 juli 2019] jam 02.22 WIB. 
Latif, Mukhtar. Dkk., (2013). Orientasi Baru Pendidikan Anak Usia Dini. Jakarta : Kencana.

Madyawati, Lilis., (2016). Strategi Pengembangan Bahasa pada Anak. Magelang. Kencana.

Menteri, pendidikan Nasional Republik Indonesia. (2010). Peraturan Menteri Pendidikan Nasional Nomor 58 tahun 2009 diakses dari http://www.paudni.kemdikbud.go.id/wpcont ent/uploAds/2012/08/permen 58 2009-ttgstandar-PAUD. Pdf. Pada tanggal 20 juli 2019 jam 20:32 WIB.

Ramadhani, Risky., (2014). Meningkatkan Keterampilan Bericara melalui Media Bercakap-cakap dengan Media Gambar. Ejournal paud Universitas Yogyakarta,173.Tersediadihttp://ejournal.U Y.ac.id/index.php/Paud/article.view.73.pdf. [diakses pada 11 juni 2019] jam 08.45 WIB. Rahmawati, Dewi Julia., (2016). Meningkatkan Keterampilan Berbicar Menggunakan Media Boneka Jari. Journal paud Universitas Nusantara PGRI Kediri,1126.Tersediadihttp://journal.UN.PG RI.Kediri.ac.id/index.php.paud/article/view/ 1126.pdf. [diakses pada 1 juli 2019] jam 11.20 WIB.

Rahmawati, Desi, Dkk., (2016). Peningkatan Keterampilan Berbicara Melalui Media Bercerita. Journal Pendidikan, fkip Universitas Lampung, 1-10. Tersedia di http://journal.fkip.UL.ac.id/index/JPAUD./1 10.01.pdf. [diakses pada 02 2019] jam 10.09 WIB.

STKIP, HAMZAR., (2019). Pedoman Penulisan Skripsi. Lombok Utara.

Susanto, Ahmad., (2015). Bimbingan dan Konseling di Taman Kanak-kanak. Jakarta ; Kencana.

Sudarna. (2014). PAUD Pendidikan Anak Usia Dini Berkarakter. Yogyakarta. Dinas Perpustakaan Daerah dan Kearsipan, Provinsi Nusa Tenggara Barat.
Suryani, Nunuk. Dkk., (2015). Media Pembelajaran Inovatif daan Pengembangannya. Bandung : PT Remaja Rosdakarya.

Sugiyono. (2016). Metode Penelitian Pendidikan Pendekatan Kuantitatif, Kualitatif dan $R \& D$. Bandung: Alvabeta.

Tarigan, Henry Guntur., (2018). Berbicra Sebagai Suatu Keterampilan Berbahasa. Bandung. Angkasa.

Trianto, Ibnu Badar al-Tabany., (2011). Desain Pengembangan Pembelajaran Tematik Bagi Anak Usia Dini TK/RA \& Anak Kelas Awal SD/MI Implementasi Kurikulum 2013. Jakarta ; Kencana. Dinas Perpustakaan Daerah dan Kearsipan, Provinsi Nusa Tenggara Barat.

Wigayuwifa. (2014). Peningkatan keterampilan Berbicara Anak Usia Dini Melalui Mediaa Gambar Berseri Kelompok B2. E-journal PAUD Universitas Bengkulu,163.Tersediadihttp://ejournal.UB. ac.id/index.php/JJPAUD/article.view/1.pdf. [diakses pada 05 juni 2019] jam 10.11 WIB. 